\title{
AMITAI ETZIONI E O PARADIGMA COMUNITARISTA: DA SOCIOLOGIA DAS ORGANIZAÇÕES AO COMUNITARISMO RESPONSIVO
}

João Pedro Schmidt

O debate sobre comunidade e comunitarismo no Brasil é crescente, mas parcela importante dos estudos ainda restringe essa corrente de pensamento aos intelectuais envolvidos no debate liberais versus comunitaristas (Walzer, Sandel, MacIntyre e Taylor), debate deflagrado a partir da publicação, em 1971, da obra Uma teoria da justiça, por John Rawls. Esse uso restrito do termo não se sustenta: há uma profusão de teorias que conferem centralidade à comunidade na vida social e se usa o termo comunitarismo há mais de um século e meio, tendo sido cunhado em 1841 por John Goodwin Barmby, com o significado de "membro de uma comunidade formada para pôr em prática teorias comunistas ou socialistas", e seu significado contemporâneo - "de, pertencente a ou característico de uma comunidade" - apareceu no dicionário Webster's, em 1909 (Etzioni, 1998, p. IX).

Em termos amplos, o comunitarismo pode ser definido como um ideário que confere centralidade à comunidade (e não ao Estado ou ao mercado) e inclui um leque de formulações filosóficas, sociológicas, políticas e econômicas, cujas raízes estão nas grandes religiões (judaísmo, cristia- 
nismo, islamismo e budismo) e na filosofia grega, perpassando todo o pensamento ocidental. Alexis de Tocqueville, Charles Fourier, Piotr Kropotkin, Ferdinand Tönnies, Emanuel Mounier, John Dewey, Robert Nisbet, Martin Buber e Amitai Etzioni são alguns dos pensadores dessa vertente de pensamento, que tem diversas matrizes: a tradição aristotélica, a tradição judaico-cristã, a tradição utópica, o liberalismo, o ideário socialista e anarquista, os estudos sociológicos sobre comunidade, o pensamento autoritário, o republicanismo e as teorias do capital social e o comunitarismo responsivo. No variado leque dessas teorias um princípio é recorrente: a comunidade é fundamental para a construção da boa sociedade. Além desse princípio, pode-se identificar um núcleo de ideias, noções e temas comuns aos diferentes autores comunitaristas, a saber: a comunidade é condição ontológica do ser humano; oposição ao individualismo e ao coletivismo; oposição ao gigantismo estatal; 94 primazia dos valores pessoais sobre os valores do mercado; subsidiariedade, poder local, associativismo e autogestão; fraternidade, igualdade e liberdade (Schmidt, 2011).

A atual reflexão acadêmica brasileira sobre o tema da comunidade e o comunitarismo vem se desenvolvendo em áreas como a filosofia, a teologia, o direito, a sociologia, a educação, a comunicação e o serviço social, e se ocupa com maior atenção de tópicos como as repercussões do debate sobre a tese social comunitarista versus a concepção liberal do indivíduo (Rennó Jr., 2000; Bellah, 1999); o potencial heurístico do comunitarismo em face de outras perspectivas filosóficas atuais (Lois, 2005; Galuppo, 2007; Trucco, 2008); a justiça redistributiva e a concepção comunitarista da moral na esfera jurídica (Cittadino, 2009; Silveira, 2007); o tratamento da diversidade cultural e étnica na perspectiva liberal e comunitarista (Costa e Werle, 1997; Lucas, 2009); o significado político do discurso comunitário na esfera pública e nas políticas sociais (Gohn, 2004; Macedo, 2005); 
o sentido da comunidade em tempos de globalização (Paiva, 2003; 2007). Enquanto parcela dos estudos destaca a relevância das contribuições comunitaristas, outra parte aponta fragilidades e insuficiências que tornam discutível sua relevância.

Entre os questionamentos acerca da pertinência das concepções comunitaristas para a realidade brasileira estão aqueles derivados das pesquisas de cultura política. Uma matriz interpretativa respeitada, apoiada em Sérgio Buarque de Holanda, Raimundo Faoro e Roberto DaMatta ressalta as singularidades culturais do cidadão brasileiro, como o personalismo, o clientelismo, o patrimonialismo, a desconfiança social e o reduzido grau de associativismo. Essa matriz não proporciona aproximações fáceis com o comunitarismo. Para Lucio Rennó Jr. (2000), por exemplo, os baixos índices de associativismo dos cidadãos e a cultura política de desconfiança são fortes obstáculos para a implementação de propostas comunitaristas.

Para contribuir com o debate em curso, este texto apresenta tópicos centrais do pensamento de Amitai Etzioni ${ }^{1}$, sociólogo israelense radicado nos Estados Unidos. Trata-se de autor de estatura intelectual reconhecida nos meios acadêmicos internacionais, com vasta produção bibliográfica ${ }^{2}$. Pensador de grande erudição, seus escritos revelam a influência de pensadores clássicos da filosofia e da

\footnotetext{
1 Amitai Etzioni nasceu na Alemanha, em 1929, com o nome de Werner Falk. Em face da ameaça nazista sua família fugiu para a Palestina. Lá, viveu sua adolescência e juventude, parte dela em kibbutz, uma experiência comunitária que o marcou profundamente. Ainda em Israel estudou com o filósofo Martin Buber, optando depois por viver nos Estados Unidos, onde estudou, tornando-se mais tarde professor nas universidades de Colúmbia, Harvard e George Washington. Intelectual público, foi inicialmente uma voz de contestação, assumindo posteriormente posições politicamente moderadas que o levaram a atuar como assessor da Casa Branca no governo de Bill Clinton.

2 A produção intelectual de Etzioni compõe-se de mais de 40 livros próprios, 20 livros editados ou coeditados, cerca de 350 artigos acadêmicos e centenas de textos de opinião divulgados na mídia.
} 
sociologia. De Martin Buber, a filosofia do diálogo e a relação Eu-Tu. De Weber, os conceitos de poder, autoridade e burocracia. De Marx, o tema dos conflitos do mundo do trabalho. De Freud, as tensões entre indivíduo e sociedade. De Durkheim, a importância dos valores sociais e laços comuns. De Tönnies, a diferenciação entre comunidade e sociedade. De Parsons, a análise funcional. De John Stuart Mill, a questão da liberdade individual. De Kant, a concepção deontológica da moral. Mas a chave de leitura de suas obras é compreendê-lo como pensamento situado: os escritos referem-se às questões do contexto das últimas décadas, especialmente o norte-americano, confrontando, por um lado, o individualismo extremado e, por outro, o conservadorismo fundamentalista. É particularmente agudo seu confronto com as teorias liberais individualistas da rational choice e da escola econômica neoclássica.

O que aproxima Etzioni de autores como Taylor, 96 Sandel, Walzer e MacIntyre é a relevância da comunidade e do bem comum, a visão de que "o liberalismo não leva em conta suficientemente a importância da comunidade para a identidade pessoal, o pensamento moral e político e os julgamentos acerca de nosso bem-estar no mundo contemporâneo" (Bell, 1993, p. 4). Entre os diferenciais que distinguem Etzioni, o primeiro é a condição autoassumida de intelectual público, o que faz de sua obra a face teórica da ação política. Ou seja, há uma intenção política "prática" a percorrer sua obra intelectual, materializada no movimento comunitarista responsivo. O segundo é o esforço para a construção de um paradigma comunitarista, ou seja, a formulação de uma teoria abrangente das dimensões fundamentais da vida em sociedade, como a política, a economia, a educação, a ética e a cultura, com o objetivo de mostrar que o comunitarismo responsivo constitui uma visão alternativa de mundo, uma terceira via em relação às concepções focadas no Estado (estatismo) e no mercado (privatismo). 
O terceiro é o caráter crítico-propositivo de seus escritos, nos quais a análise crítica de diferentes posições sobre determinado tema é complementada pela apresentação de proposições para a ação. Enquanto o debate liberais versus comunitaristas ocorre em boa parte no plano dos princípios e das teses gerais, Etzioni desce constantemente ao plano das questões políticas e sociais cotidianas.

\section{A sociologia das organizações}

As obras de Etzioni traduzidas e estudadas no Brasil são as da sua fase inicial (décadas de 1950 e 1960), voltadas à análise das organizações. Nessas, pouco se fala de comunidade, não se realça sua importância na vida social e não há nenhum discurso comunitarista explícito. Em obras como Organizações modernas, Organizações complexas e Análise comparativa de organizações complexas, Etzioni parte da constatação de que a sociedade moderna é fundamentalmente uma sociedade de organizações. Organizações já existiam nas sociedades antigas, mas sua relevância nos tempos modernos é outra: "Nascemos em organizações, somos educados por organizações e quase todos nós passamos a vida a trabalhar para organizações”, considera Etzioni (1974, p. 7), salientando que constituem um meio mais eficiente de satisfazer as necessidades da sociedade atual que a proporcionada pelos agrupamentos menores e mais naturais, como a família, os amigos e as comunidades.

As organizações são tomadas como unidades sociais "intencionalmente construídas e reconstruídas, a fim de atingir objetivos específicos" (Etzioni, 1976, p. 9). Diferentemente da literatura da época, focada nas organizações públicas e nas empresas, Etzioni amplia o foco da sociologia organizacional ao desenvolver estudos sobre outros agrupamentos como escolas, universidades, hospitais e prisões, ficando excluídas coletividades como tribos, classes, comunidades, famílias e grupos étnicos, por não atender três 
características básicas: divisões de trabalho, poder e responsabilidade de comunicação; presença de um ou mais centros de poder; e substituição de pessoal.

A abordagem etzioniana é denominada estruturalista e alinhada ao funcionalismo. $\mathrm{O}$ autor faz uma síntese da escola clássica (formal) e da teoria das relações humanas, inspirado em Weber e, até certo ponto, em Marx. "Estrutural”, em Etzioni (1976), refere-se aos aspectos comuns a todas as organizações: todas devem cuidar de recrutamento, treinamento, socialização, motivação, coordenação, controle e comunicação; em todas há uma relação dinâmica entre as metas organizacionais e as necessidades internas e externas de adaptação ao ambiente variável.

Etzioni (1976) enfrenta criticamente a teoria das relações humanas e sua visão de harmonia, destacando que são insolúveis as tensões que perpassam todas as organizações: tensões entre necessidades da organização e de seu pesso98 al, entre racionalidade e irracionalidade, entre disciplina e autonomia, entre relações formais e informais, entre administração e trabalhadores. $\mathrm{O}$ conflito é inerente às organizações e fator de desenvolvimento. Quanto ao trabalho, há muitas maneiras de torná-lo mais agradável, mas nenhuma de torná-lo satisfatório, em termos absolutos. O viés funcionalista é evidente, embora o autor rejeite uma concepção estática de sociedade e insista na dinamicidade da vida em sociedade, apontando os conflitos como importantes fatores de mudança.

Situada entre as abstrações de alto nível e as observações detalhadas sobre casos singulares, o autor construiu uma teoria organizacional intermediária, valendo-se da análise comparativa, na expectativa de estabelecer proposições universais, reduzir as proposições excessivamente genéricas a proposições de nível médio e desenvolver novas proposições de nível intermediário. Na comparação entre as organizações utilizou como variável o consentimento, uma "relação 
que consiste no poder empregado pelos superiores para controlar os subordinados e a orientação destes em relação àquele poder", por permitir combinar a dimensão estrutural com a motivacional (Etzioni, 1974, p. 15). O estudo do consentimento é, segundo ele, importante tanto para a compreensão das organizações quanto para a da ordem social, envolvendo sempre controle e construção do consenso. Há três formas principais de controle social: a coerção, os bens econômicos e os valores normativos. Nenhuma delas tem superioridade a priori, devendo o estudo comparativo mostrar qual se impõe numa determinada organização. $\mathrm{O}$ autor relaciona o consentimento a duas outras variáveis: o poder e a participação. O primeiro se classifica em poder coercivo, remunerativo e normativo, ao passo que a segunda se classifica em participação alienativa, calculista e moral.

A contribuição de Etzioni para o estudo das organizações é reconhecida na literatura da ciência administrativa e da sociologia organizacional (Dias, 2008). A concepção estruturalista é considerada um momento da evolução das concepções administrativas rumo à abordagem sistêmica ${ }^{3}$, com a qual compartilha o esforço de levar em conta o conjunto dos fatores, endógenos e exógenos, que influem na vida organizacional. Entre seus méritos reconhecidos estão os de ter favorecido a precisão conceitual e metodológica da sociologia organizacional, o desenvolvimento de uma metodologia comparativa das organizações, os avanços na análise do tema da burocracia, sugerindo uma releitura da teoria de Weber, ter assinalado a importância do conflito nas organizações e a insistência na visão de conjunto acerca das organizações, tanto dos elementos internos como ambientais, perspectiva depois desenvolvida pela abordagem sistêmica.

\footnotetext{
3 The active society, publicada em 1968, é uma densa obra de teoria sociológica em que Etzioni elabora uma concepção sistêmica, apoiada na cibernética. Essa obra, de diversos aspectos, é uma ponte entre a fase inicial e a fase comunitarista do autor.
} 
Não há comunitarismo explícito nessas obras iniciais de Etzioni. O tema da comunidade não tem qualquer destaque na sociologia organizacional, sendo mencionado apenas de passagem, quando da análise das mútuas influências entre as organizações e seu ambiente contextual. Com isso não se sugere que haja contradições ou oposições entre a fase da teoria organizacional e a da formulação comunitarista, e, sim, se destaca que as ideias nucleares do paradigma comunitarista, amadurecido a partir dos anos 1990, não são antecipadas na fase inicial. Em suas memórias, o autor diz que o elo é o tema da moral, central ao comunitarismo ${ }^{4}$ : em seus escritos iniciais sobre sociologia organizacional há um subtexto moral, pouco notado, ou seja, a mensagem de que "as organizações que apelam aos valores de seus membros são superiores às que se apoiam em incentivos e muito melhores que as que empregam a força” (Etzioni, 2006, pp. 82-83).

Outra faceta da produção de Etzioni conhecida no Bra100 sil é a concepção do processo decisório nas organizações e nas políticas públicas como sondagem mista, uma abordagem alternativa ao racionalismo e ao incrementalismo. Os modelos racionalistas, presentes nas teorias da rational choice, não consideram a limitação das informações disponíveis, superdimensionam a capacidade de processamento daquelas e não levam em conta a influência dos valores e das emoções, devendo ser rejeitados por serem "irrealistas e indesejáveis". Os incrementalistas rejeitam a possibilidade de condução das políticas por instituições centrais, entendendo que estas são resultado de concessões mútuas entre as numerosas facções da sociedade, e que nas democracias maduras as

\footnotetext{
4 Embora Etzioni saliente a importância da moral e a superioridade das organizações apoiadas no consentimento normativo, reconhece a importância do fator material e remunerativo. Uma de suas críticas contundentes à teoria das relações humanas é o plano secundário em que esta coloca as recompensas: "Embora se tenha verificado que as recompensas sociais são importantes nas organizações, isso não diminui a importância das recompensas materiais" (Etzioni, 1974, p. 79).
} 
políticas não passam de ações incrementais em relação à situação vigente, sendo irrealistas as expectativas de grandes mudanças. Etzioni (2009a; 2009b) concorda com a crítica dos incrementalistas aos excessos racionalistas, mas avalia que o incrementalismo acaba sendo um "reforço ideológico das forças pró-inércia e anti-inovação”. Defende uma terceira posição, que aproveite do incrementalismo a recusa do detalhamento excessivo e do racionalismo a inclusão das decisões num contexto amplo e de planejamento de longo prazo. Sua proposta é a sondagem mista, "um modo hierárquico de tomada de decisão que concilia decisão fundamental, de ordem superior, com decisões incrementais, de ordem inferior; estas abrem caminho para as de ordem superior e/ou levam-nas a cabo" (Etzioni, 2009b, pp. 23334). A tese da racionalidade limitada e balanceada por valores e emoções é um elemento do paradigma sociopolítico do autor, retomada e aprofundada em publicações recentes.

Estudiosos das políticas públicas consideram a sondagem mista uma abordagem original e relevante, com recomendações heurísticas apreciáveis, especialmente na fase de identificação dos problemas, mas frágil quanto à definição de regras sobre o uso do arbítrio nas decisões e de fornecer conceitos acessíveis aos agentes das políticas, o que torna discutível sua condição de terceira abordagem da tomada de decisão (Heidemann e Salm, 2009).

A partir da década de 1990, as obras comunitaristas de Etzioni começam a ser publicadas, paralelamente à emergência do movimento comunitarista no cenário norte-americano, cujas linhas gerais são apresentadas a seguir.

\section{O movimento comunitarista responsivo}

Em novembro de 1991 foi divulgada a plataforma programática do movimento comunitarista responsivo - The Responsive Communitarian Platform: Rights and Responsibilities -, que ainda hoje constitui o documento referencial dos responsi- 
vistas norte-americanos. A versão inicial foi formulada por Etzioni e discutida por um grupo de intelectuais vinculados a distintas linhas de pensamento, sendo o documento assinado por 104 personalidades, entre as quais intelectuais, lideranças feministas, negras e hispânicas, representantes religiosos, republicanos e liberais moderados. A lista dos primeiros signatários inclui, além do autor, personalidades internacionalmente conhecidas como Benjamin R. Barber, Robert N. Bellah, Harvey Cox, James Fishkin, Betty Friedan, Francis Fukuyama, Wiliam Galston, Mary Ann Glendon, Albert O. Hirschman, Alejandro Portes, Philip Selznick, Thomas Spragens, Lester C. Thurow e Dennis H. Wrong 5 .

Entre as linhas básicas da plataforma estão: a importância da comunidade na existência humana; o indispensável equilíbrio entre a liberdade e a responsabilidade, entre o bem comum e a autonomia individual; o papel da voz moral diante do Estado e do mercado, exercido pela persuasão e 102 pela educação; o fortalecimento da democracia mediante o incremento da representação, da participação e da responsividade da política em relação aos cidadãos; a centralidade dos valores e dos deveres cívicos, da ética na política; a afirmação da democracia forte, não apenas majoritária; a necessidade de repensar e apoiar a família, primeira linha de defesa da educação moral; a formação do caráter como papel principal da escola, segunda linha de defesa; a relevância do fortalecimento das comunidades e do espírito comunitário; a defesa da saúde pública; a perspectiva cosmopolita do comunitarismo responsivo. O documento mostra a clara opção pela terceira via, um caminho alternativo à esquerda e à direita norte-americanas, sem deixar de contemplar valores centrais de uma e outra, especialmente as questões da liberdade e da autonomia individual, prezadas

\footnotetext{
5 O documento não foi assinado por Taylor, Sandel, Walzer e MacIntyre. Todavia, os três primeiros mantiveram relações de diálogo e participaram de publicações do movimento comunitarista responsivo.
} 
pela esquerda, e as da moral e da ordem, substanciais no ideário da direita.

A escolha do adjetivo responsivo (responsive) deu-se no contexto das preocupações em se diferenciar de outras formas de comunitarismo, particularmente do modelo comunista e do modelo asiático. Enquanto aquele se caracterizou pelo viés estatizante e coletivista, este, segundo Bell (2009), distingue-se pela ênfase na família, na harmonia social e na precedência do social, sendo que ambas as perspectivas rejeitam os valores liberais da autonomia individual, da sociedade civil e das liberdades políticas. O comunitarismo responsivo, de forma equidistante, postula o equilíbrio entre comunidade e indivíduo. O termo responsivo, explica Etzioni (1998; 2003), foi escolhido para explicitar a preocupação dos comunitaristas em dar respostas às pessoas, em serem sensíveis aos anseios do povo e deixar clara sua diferença tanto em relação aos comunistas como aos comunitários autoritários do Leste Asiático.

Enquanto os antigos comunitaristas tendem a enfatizar a importância das forças sociais, da comunidade, dos vínculos sociais (e no caso dos comunitaristas asiáticos, da harmonia social) [...] os novos comunitaristas estão preocupados desde o início com o equilíbrio entre as forças sociais e a pessoa, entre comunidade e autonomia, entre bem comum e liberdade, entre direitos individuais e responsabilidades sociais (Etzioni, 1998, p. x).

Os responsivistas optaram por constituir um movimento social sem vínculo com agremiação política ou organização não governamental. Sua ação pública foi em grande parte descentralizada, cada membro atuando no meio acadêmico, político ou social com base nas premissas contidas na plataforma, nas publicações e nos debates. A mídia foi o seu principal meio de divulgação. Na década de 1990, a 
imprensa norte-americana passou a abordar com frequência as posições comunitaristas, ainda mais porque os presidentes Bill Clinton e George Bush incluíram teses comunitárias em seus pronunciamentos e em sua plataforma de ação. Um grupo de comunitaristas, incluindo William Galston e Amitai Etzioni, integrou o governo de Bill Clinton por algum tempo, mas o conjunto do movimento nunca se assumiu como democrata ou republicano.

Politicamente, o movimento responsivo posicionou-se ao centro do espectro ideológico, apresentando-se como terceira via, em favor da renovação do projeto do Welfare State. No terreno da política interna norte-americana, o movimento colocou-se como alternativa aos excessos dos neoconservadores, por um lado, e dos libertários, por outro. Economicamente, faz a defesa do mercado regulado por valores sociais, opondo-se claramente ao neoliberalismo: "a chave da abordagem comunitária para a economia é a bus104 ca de equilíbrio entre a livre iniciativa e o bem social, entre o mercado e o governo, entre a liberdade econômica e as necessidades mais amplas da sociedade”.

O movimento comunitarista manteve entre 1991e 2004 uma revista quadrimestral, denominada The Responsive Community: Rights and Responsibilities, voltada ao debate e à difusão da visão comunitarista acerca de temas como teoria comunitarista, filosofia e políticas públicas. Hoje, são três suas principais expressões públicas. The Communitarian Network é "uma coalizão de indivíduos e organizações que se uniram para reforçar o ambiente social, moral e político", de caráter apartidário, não sectário e transnacional, que organiza diálogos, promove reuniões públicas, aconselha legisladores e grupos comunitários em questões morais e sociais e difunde o comunitarismo ${ }^{6}$. O Institute for Communitarian Policy Studies, vinculado à George

${ }^{6}$ Cf. <http://communitariannetwork.org>. Acesso em: 27 dez. 2014. 
Washington University, é um centro de pesquisa de políticas comunitárias, destinado a "encontrar soluções construtivas para os problemas sociais através da análise política moralmente informada e diálogo moral"7.

A International Society for the Advancement of SocioEconomics (SASE), fundada em 1989, é uma organização internacional e interdisciplinar voltada ao desenvolvimento e à difusão da socioeconomia. A SASE é uma das mais influentes organizações internacionais de formulação de pensamento econômico alternativo à ortodoxia liberal, com membros em mais de 50 países nos cinco continentes. As disciplinas acadêmicas representadas na sociedade incluem economia, sociologia, ciência política, administração, psicologia, direito, história e filosofia. Entre seus membros estão empresários, decisores governamentais e organizações internacionais ${ }^{8}$.

Essas informações sobre o movimento comunitarista permitem apreender o sentido mais global da teoria comunitarista de Etzioni, cujos grandes temas passam a ser apresentados.

\section{0 pensamento comunitarista de Etzioni}

A condição de principal expoente do movimento comunitarista responsivo está associada diretamente à produção intelectual de Etzioni sobre o comunitarismo, cujas obras são publicadas a partir do fim da década de 1980. Antes disso, o autor já havia avançado linhas importantes ao escrever sobre temas como transformação social, paz, democracia, corrupção e agenda da reconstrução norte-americana, mas a explicitação das categorias nucleares do comunitarismo aparece fundamentalmente a partir da obra The moral dimension: towards a new economics (1988), seguida de The spirit of community: the reinvention of American society (1993), The

Cf. <http://icps.gwu.edu>. Acesso em: 27 dez. 2014.
Cf. <http://www.sase.org > Acesso em: 27 dez. 2014.

Lua Nova, São Paulo, 93: 93-138, 2014 
New Golden Rule: community and morality in a democratic society (1996), The third way to a good society (2000) e The common good $(2004)^{9}$. Essa produção revela um intelectual com preocupações e abordagem totalmente distintas da fase inicial. Agora o tema é a comunidade, que constitui o núcleo da boa sociedade como espaço de produção e formulação da moral. A preocupação em lapidar o paradigma sociopolítico, próprio da terceira via comunitarista, é notória em todos os escritos. $\mathrm{O}$ estilo não é de um sociólogo que analisa alguma faceta da vida em sociedade e, sim, de um intelectual preocupado em sistematizar uma visão de mundo, embora insista em afirmar que o paradigma sociopolítico seja uma nova ideologia. $\mathrm{O}$ autor não nega a influência funcionalista, explícita na fase inicial, mas as referências passam a ser amplas: Martin Buber, Taylor, Selznick e outros comunitaristas, Adam Smith, Stuart Mill e os liberais, Marx e os socialistas, Barber e os teóricos da democracia, para citar alguns. 106 Ou seja: o Etzioni da sociologia organizacional pouco revela do Etzioni comunitarista.

\section{A comunidade e sua relevância para a boa sociedade}

A literatura sociológica registra uma infinidade de definições de comunidade, o que tem levado vários autores a negar o próprio conceito. Etzioni (1995) opõe-se à alegação de que a profusão de noções de comunidade revela a ausência de um conceito aceitável, argumentando que há, sim, um conceito claro e empiricamente verificável: as comunidades são os grupos humanos caracterizados por relações de afeto e pelo compartilhamento de valores e significados.

\footnotetext{
${ }^{9}$ São utilizadas ao longo do texto as traduções disponíveis em língua espanhola para as obras: The moral dimension: toward a new economics, 1988 (La dimensión moral: hacia una nueva economia, 2007); The new golden rule: community and morality in a democratic society, 1996 (La nueva regla de oro: comunidad y moralidad en una sociedad democrática, 1999a), The third way to a good society, 2000 (La tercera vía hacia una nueva sociedad, 2001a).
} 
Comunidade é uma combinação de dois elementos: (a) Uma rede de relações carregadas de afeto entre um grupo de indivíduos, relações que frequentemente se cruzam e se reforçam umas às outras (em vez de tão somente relações individuais, uma a uma ou encadeadas). (b) Uma medida de compromisso com um conjunto de valores compartilhados, normas e significados, e uma história e identidade compartilhadas - em resumo, com uma cultura particular (Etzioni, 2001b, pp. 142-43).

Para Etzioni, as relações de afeto e o compartilhamento de valores e significados continuam sendo comuns hoje em muitos grupos, constituídos com base em vínculos residenciais, profissionais, religiosos, culturais, étnicos, de orientação sexual, políticos ou outros. As comunidades de nossos dias apresentam características diferentes daquelas das sociedades tradicionais. Nas sociedades agrárias predominavam as comunidades territoriais, residenciais, ao passo que nas sociedades atuais há variados fatores que aproximam as pessoas. O conceito, para ele, se aplica também ao mundo virtual. As comunidades virtuais têm características próprias, com limitações e vantagens em relação às presenciais, mas não há dúvida de que afeto e partilha de valores morais podem permear as relações virtuais (Etzioni, 2001b, pp. 96 e ss.; 2004, cap. 4).

\section{Relações Eu-Tu.}

As comunidades são o ambiente das relações Eu-Tu (ou Eu-Nós), as relações baseadas em fins, enquanto o mercado é o reino das relações Eu-Isso, relações baseadas em meios. A boa sociedade é definida por Etzioni como aquela em que as pessoas se tratam como fins e não como meios, concepção apoiada na formulação de Martin Buber, filósofo que desenvolveu uma profunda filosofia da relação e do diálogo, cujo núcleo é a distinção entre as palavras-princípio Eu-Tu e Eu-Isso. A 
primeira constitui o mundo da relação e da presença imediata e a segunda, o mundo da experiência e da objetividade. "A relação com o Tu é imediata. [...] Entre Eu e Tu não há fim algum, nenhuma avidez ou antecipação [...] Todo meio é obstáculo. Somente na medida em que todos os meios são abolidos, acontece o encontro" (Buber, 2001, p. 57). No pensamento de Buber, a relação autêntica, imediata, entre os seres humanos, sem outro fim ou interesse para além do encontro, é fugaz e cheia de obstáculos e seu ambiente natural é a comunidade. As relações Eu-Isso, próprias do mercado, são importantes para a vida humana, mas jamais podem preceder as relações Eu-Tu.

Relevância social das comunidades.

As comunidades têm um decisivo papel na construção da boa sociedade e para o bem-estar dos seres humanos. De Kant a Marx, lembra Etzioni, grande parte da filosofia social 108 partilha a visão de que o predomínio da orientação instrumental nas relações sociais é uma das maiores ameaças ao bem-estar das pessoas. Os resultados de inúmeras pesquisas científicas comprovam tal entendimento ao mostrar que a saúde física e mental está associada à integração das pessoas em ambientes marcados por relações afetivas, ao passo que as doenças (psíquicas, alcoolismo, drogadicção etc.) são derivadas de situações de vida marcadas pelo isolamento e pela solidão. Os processos de fortalecimento das comunidades são o melhor meio de enfrentar esses males: terapias, tratamento para drogas e álcool e delinquência juvenil são mais eficazmente desenvolvidos por programas apoiados no fortalecimento da comunidade (Etzioni, 2001a).

As comunidades exercem uma função moral fundamental. Além da voz moral interior (pessoal), há a voz moral comunitária, exterior ao eu e que pode reforçar a voz pessoal. Ao compartilhar e reafirmar os valores comunitários, estimulando seus membros a orientarem sua conduta por eles e 
censurando-os quando não o fazem, as comunidades são elementos indispensáveis para a precedência dos meios normativos sobre os meios coercitivos. Quanto mais eficazes são os meios normativos, menor é a necessidade de coerção. Pesquisas empíricas mostram que há forte conexão entre vínculo afetivo e voz moral: "as pessoas seguem mais facilmente a voz moral de outras pelas quais se preocupam, daquelas com que têm laços afetivos; isto é, os membros de sua comunidade" (Etzioni, 1996, p. 155). Isso, porém, não assegura que o seguimento da voz moral seja algo necessariamente positivo, nem que todas as comunidades sejam automaticamente boas. Os valores morais compartilhados e sustentados pela comunidade é que permitem dizer se uma comunidade é boa. Entre os valores são particularmente destacados por Etzioni aqueles que dizem respeito ao equilíbrio entre o bem comum e a autonomia individual: "comunidades não são boas por si; apenas comunidades que exibem certos atributos, um balanço entre vínculos e proteção do self, podem ser qualificadas como boas" (Etzioni, 2001b, pp. 144-45). O inimigo a combater não é apenas o enfraquecimento dos laços comunitários, mais comum no Ocidente, mas também o seu oposto: a supersocialização, o sufocamento e a opressão dos indivíduos no seio da comunidade.

\section{Comunidades e democracia}

Muitos estudiosos denunciam o caráter autoritário e opressivo das comunidades ao longo da história. Zygmunt Bauman (2003) assinala que a segurança proporcionada pelas comunidades tem tido muitas vezes como preço a perda da liberdade e da autonomia individual. Etzioni reconhece a legitimidade dessa crítica (lembrando que essa se aplica também ao Estado e ao mercado), mas contrapõe que nas sociedades democráticas modernas muitas comunidades praticam internamente a democracia e, além disso, é comum o multipertencimento comunitário: muitos indi- 
víduos participam de mais de uma comunidade (religiosa, política, étnica, cultural etc.), o que lhes permite escolher as mais condizentes com a liberdade individual (Etzioni, 1999a; 2001a; 2001b).

Os conflitos são intrínsecos à vida humana e estão presentes na comunidade. Não é possível nem desejável suprimi-los. O que é próprio da comunidade é o tratamento dos conflitos no âmbito dos vínculos, dos compromissos e dos valores que definem o conjunto. As desigualdades também são próprias da comunidade. Etzioni não acredita nem propõe uma visão igualitarista completa, mas postula que a perspectiva comunitarista é em favor da redução das desigualdades e da garantia de um mínimo de riqueza a todos: "A boa sociedade é aquela em que a desigualdade em cada comunidade e entre elas é significativamente reduzida. Igualdade per se não está sob consideração” (Etzioni, 2001b, p. 149).

110 Comunidade de comunidades

A concepção comunitarista de Etzioni de modo algum é localista ou particularista. A expressão comunidade de comunidades usada por Martin Buber (2006) é constantemente evocada pelo autor: a região é uma comunidade de comunidades locais, o país é uma comunidade de comunidades locais e regionais ${ }^{10}$ e o mundo é uma comunidade de comunidades nacionais. O comunitarismo é cosmopolita, planetário. A articulação das comunidades é a via para enfrentar as cisões e guerras entre povos, a falta de sintonia entre os poderes centrais e as populações locais, bem como as múltiplas formas de antagonismo que colocam a própria sobrevivência da humanidade em risco (Etzioni, 2004).

\footnotetext{
${ }^{10}$ Etzioni considera que o Estado-nação mantém sua importância nos dias atuais, mas revela grande preocupação em relação aos nacionalismos extremados, que consideram coextensivos a comunidade e o país, o pertencimento comunitário e a cidadania. É o que ocorreu, diz ele, com a concepção nazista da Volksgemeinschaft, no qual o comunal foi absorvido pelo nacional (Etzioni, 2004, p. 165).
} 


\section{Concepção antropológica}

A concepção comunitarista está a meio caminho entre a visão

otimista dos individualistas e a visão sombria dos social-conservadores: é a concepção dinâmica, cuja premissa central é a natureza social do ser humano. "O homem não é senão um ser social: o que ele é depende do seu ser social e o que ele faz de seu ser social é irrevogavelmente ligado ao que ele faz de si mesmo" (Etzioni, 1968, p. 2). Os achados científicos trazem inúmeras evidências em favor da tese comunitária que atesta que para existir o eu deve haver o nós. Como Taylor, opõe-se às teses atomistas, que conduzem ao individualismo e ao ativismo individual inconsequente, e elabora uma concepção que vincula a parte (o indivíduo) ao todo (a sociedade e suas estruturas). O homem é um ser de relação, ontologicamente condicionado pela existência com os outros. Sob as diferenças entre as pessoas, Etzioni vislumbra uma natureza humana universal.

Como eu o vejo, a natureza humana é universal; nós somos - homens e mulheres, negros, marrons, amarelos, brancos e assim por diante - todos basicamente o mesmo sob as camadas e culturas adotadas e impostas sobre nós. Eu vejo uma grande quantidade de evidência de que as pessoas de diferentes eras, sociedades e condições mostram as mesmas inclinações básicas. [...] Há um forte acúmulo de evidência de que as pessoas têm uma profunda necessidade de vínculos sociais (ou ligações) e uma imperiosa necessidade de orientação normativa (ou moral) (Etzioni, 1996, p. 33).

Não há virtudes inatas que nos conduzam sem esforço ao bem, nem vícios inatos que nos condenem ao mal. A magnitude da virtude humana depende de três condições: (i) a internalização dos valores; (ii) a evolução das formações sociais; e (iii) a redução da contradição inevitável entre plena ordem e plena autonomia. A socialização exerce um 
papel fundamental ao longo da vida: "a pessoa comunitária é, pois, alguém que está continuamente em conflito entre os chamamentos da natureza (moldados pela cultura da sociedade) e a voz moral, uma pessoa 'condenada' a lutar entre um eu inferior e um eu superior" (Etzioni, 1999a, pp. 203-04). O reforço dos compromissos morais ao longo da vida é indispensável para assegurar que a virtude prevaleça na conduta pessoal (Etzioni, 2004).

Essa concepção antropológica implica a desnecessidade de heróis abnegados para viabilizar a comunidade. Viver em comunidade não pressupõe a crença na necessidade de um ser humano heroico, altruísta e disposto a sacrificar-se em nome do coletivo. A vida em comunidade assenta-se na condição social dos humanos, naturalmente seres de relação, vocacionados ao convívio social, necessitados de relações afetivas próprias da vida comunitária e, ao mesmo tempo, de autonomia individual. Os seres humanos de modo geral estão habilitados à vida

112 em comunidades que combinam o bem comum com a autonomia individual.

Os programas comunitários e as políticas públicas não devem basear-se em chamamentos heroicos. As boas sociedades limitam o estímulo a programas morais heroicos - aqueles apoiados em exigências acima das características naturais dos seres humanos - e optam por programas condizentes com os limites e as potencialidades humanas.

A concepção antropológica equivocada do paradigma liberal neoclássico é um tema reiteradamente abordado por Etzioni. Tal paradigma apoia-se em premissas falsas, como as de que os seres humanos são movidos fundamentalmente pelo prazer, bem como são capazes de conduzir-se amplamente pela razão. Contra a suposição neoclássica de que as pessoas buscam maximizar a própria utilidade (prazer, felicidade, consumo), o paradigma sociopolítico (ou comunitário) afirma que as pessoas têm duas fontes de valoração: prazer e moralidade. E, ao invés da suposição neoclássica de que 
as pessoas tomam decisões fundamentalmente racionais, o pressuposto comunitarista é o de que as pessoas selecionam os meios à base de seus valores e emoções.

Os seres humanos jamais são puramente racionais. A racionalidade é limitada pelo componente emocional, que está sempre presente. A capacidade racional é limitada e as decisões são sempre sub-racionais. Etzioni propõe uma posição moderadamente pessimista, que vale tanto para as pessoas comuns como para os cientistas: "Assim, em vez de ver as pessoas como aficionados cientistas, vemos os cientistas simplesmente como algo mais dotados, equipados, treinados e frios que os cidadãos comuns, mas também sub-racionais" (Etzioni, 2007, p. 166). A ciência é um guia insuficiente para a ação humana, pois a análise científica procede por fragmentação dos fenômenos que estuda, enquanto a ação requer relacionar-se com uma gama de elementos que envolvem o fenômeno. Por isso, nós, os humanos, enfrentamos o mundo complexo e mutante de um modo distinto da simples aplicação de um conjunto de variáveis especializadas. E grande parte das decisões individuais é influenciada pelas coletividades sociais, que são (ou podem ser) mais racionais que seus membros individualmente e que têm maior peso nas mudanças de tomada de decisões individuais que as características individuais. Isso significa que a análise socioeconômica da deliberação e decisão não deve começar pelos indivíduos e, sim, pelas coletividades sociais às quais esses indivíduos pertencem (Etzioni, 2007, pp. 243 e ss.).

\section{Concepção moral}

Chama a atenção a ênfase de Etzioni na relevância da dimensão moral para a boa sociedade, o que o aproxima de autores do espectro conservador. Etzioni tem uma explicação bastante clara a esse respeito: a moral é uma dimensão essencial à vida em sociedade, mas sua importância em geral é realçada apenas pelos social-conservadores e olvidada pelos liberais e 
pela esquerda. Isso tem levado a sociedade à visão de que as pautas morais são um patrimônio dos setores conservadores, que se beneficiam disso ao agregar politicamente grandes contingentes de cidadãos preocupados com as questões morais. É imperiosa a elaboração de uma concepção moral progressista, a formação de um centro democrático moral, e o comunitarismo responsivo assumiu essa como uma tarefa intelectual central $^{11}$ (Etzioni, 2006).

Por moral, Etzioni (2004, p. 151) entende "um leque de valores morais-sociais - de considerações normativas ou de 'deveria', incluindo justiça e igualdade, não apenas de valores pessoais como veracidade e reputação, um conjunto de valores mais pessoais e limitados". Os valores morais são condicionantes fundamentais do comportamento humano. De forma similar ao que propõem os estudos de cultura política e de socialização política, o autor entende que o comportamento é em boa parte consequência de condicio114 nantes socioculturais (valores, crenças) e, em parte menor, de cálculo racional.

Diferentemente de outros comunitaristas, o autor assume uma concepção moral moderadamente deontológica, seguindo a diretriz ética proposta por Kant. A palavra grega deon significa dever vinculante. "A essência da posição deontológica é a noção de que as ações são moralmente corretas quando se conformam a um princípio ou dever relevante" (Etzioni, 2007, p. 42). A deontologia opõe-se frontalmente ao utilitarismo do paradigma neoclássico liberal, que justifica as ações humanas com base em sua utilidade para o maior número de pessoas. O critério adotado pela deontologia para julgar a moralidade

\footnotetext{
11 "Os liberais deixam a agenda e a infraestrutura moral à direita religiosa; o país necessita de um centro 'democrático' moral. [...] [Os liberais] seguiam centrando-se no desemprego, na desigualdade, no racismo e demais assuntos importantes. Mas não tinha sentido sociológico, ético ou político abandonar os problemas causados pela deterioração dos cimentos morais da sociedade à direita religiosa. Era necessário enfrentar também esses assuntos cruciais, mas de uma maneira nova" (Etzioni, 2006, p. 220).
} 
de um ato é o dever moral que cumpre ou do qual descuida. As consequências importam, mas são secundárias. A insistência é na observância das regras morais (Etzioni, 2006; 2007).

\section{Voz moral}

A boa sociedade, a sociedade comunitária, apoia-se muito mais na voz moral que na coerção. A expressão voz moral é adequada, segundo o autor, porque as pessoas a ouvem, à exceção dos sociopatas. A voz moral é "uma forma peculiar de motivação: alenta as pessoas a aderirem aos valores que subscrevem" (Etzioni, 1999a, p. 150). A voz moral interna insta a pessoa a orientar-se pelos valores aos quais adere e abster-se de condutas que os contrariem. A voz moral comunitária estimula seus membros a terem uma conduta coerente com os valores da comunidade. A influência da voz moral sobre a conduta das pessoas tende a ser mais forte quando a voz interna é reforçada pela voz comunitária, e a voz moral da comunidade é mais eficaz quando apela a valores já estabelecidos. Quanto mais eficaz é a voz moral, menos necessária é a coerção. Muitos dos agudos problemas sociais atuais, incluindo o crescimento da violência e da criminalidade, estão relacionados à perda da força moral das comunidades, levando amplos segmentos da sociedade a pedir aos governos mais repressão e coerção, sem êxito. A estratégia para o enfrentamento dos grandes problemas sociais requer um esforço para que as comunidades retomem seu papel moral em favor da coesão e da ordem social.

Os esteios da educação moral: família, escola e comunidade

A família, a escola e a comunidade desempenham papel fundamental na formação e na disseminação de valores morais construtivos, cujo debilitamento leva fatalmente ao enfraquecimento da ordem social voluntária e à necessidade do aumento da coerção. Etzioni compartilha do pressuposto de que os primeiros anos são fundamentais para a 
formação moral da pessoa. Por isso, está particularmente preocupado com as rápidas e profundas transformações da configuração familiar e seu impacto sobre as crianças: o pouco tempo dedicado pelos pais aos filhos em razão de trabalho e outros envolvimentos, o déficit parental e de filhos, o incremento de divórcios e separações e as novas formas de matrimônio são exemplos de mudanças cujo impacto sobre as crianças requer políticas públicas específicas, elaboradas por especialistas. São urgentes ações de fortalecimento das famílias, incluindo a preparação ao matrimônio, medidas socioeconômicas que estimulem a geração e cuidado de filhos e ações em prol do reconhecimento do papel da família na sociedade. Para os comunitaristas, a família desejável é biparental, tendo pais e mães os mesmos direitos e responsabilidades, ambos preocupados com a continuidade das relações familiares no tempo, dedicando bastante tempo e comprometidos com a boa educação 116 moral dos filhos (Etzioni, 1993a, cap. 2; 1999a, pp. 213 e ss.; 2001a, pp. 68 e ss.).

A escola tem como missão primeira a formação do caráter pessoal, que, em essência, significa a aquisição da "capacidade de controlar os próprios impulsos e automobilizar-se em prol de atos para além da mera satisfação de necessidades biológicas e desejos imediatos" (Etzioni, 1993a, p. 91), o desenvolvimento de capacidades próprias, de um eu superior e mais forte, habilitado à ação cívica e moral. A recusa de muitas escolas norte-americanas em assumir explicitamente a tarefa da formação do caráter em nome da livre adoção de valores olvida o fato de que é impossível à escola não afetar os valores morais de seus alunos. Não há educação moralmente neutra. Por isso, a posição comunitarista é a favor de uma educação moral e cívica mediante palavras e atos. Os valores a serem ministrados são aqueles próprios do núcleo moral e democrático da sociedade. Os esportes coletivos são meios para ensinar disciplina e controle dos 
impulsos. O tratamento dado às pequenas e grandes infrações às regras da escola é oportunidade de aprendizagem acerca do respeito às normas sociais (e da necessidade de mudança em certos casos). Comprometidas com a democracia, as escolas não devem deixar de reconhecer abertamente o papel da autoridade. A educação cívica deve incluir oportunidades de praticar habilidades cívicas, como o serviço voluntário à comunidade e tarefas de tutoria. $\mathrm{O}$ reconhecimento do papel da religião não deve implicar a adoção de uma em particular. A educação sexual não deve ser vista como tema técnico e, sim, como tema repleto de valores, abrangendo desde o respeito aos outros até as condutas sociais responsáveis. A ênfase na formação do caráter não significa o desmerecimento da dimensão cognitiva: a autodisciplina é fator fundamental para a concentração nos estudos e para a aquisição de habilidades (Etzioni, 1993a; 1993b; 1999a; 2001a).

\section{Negação do particularismo e do relativismo moral}

Os valores morais discutidos e avalizados democraticamente no interior das comunidades conferem-lhe legitimidade maior do que as simplesmente apoiadas na tradição ou impostas autoritariamente. Mas não é a simples validação pela maioria que confere legitimidade moral, nem as comunidades têm a autoridade moral suprema. São indispensáveis freios e contrapesos sociais às próprias comunidades, assim como ao Estado e ao mercado. Etzioni não faz qualquer concessão ao relativismo e ao particularismo baseado na comunidade. $\mathrm{O}$ fato de uma comunidade legitimar em $100 \%$, por exemplo, o trabalho infantil, o matrimônio de crianças com pessoas adultas ou a mutilação sexual feminina não confere legitimidade moral a tais práticas. "Portanto, a nenhuma comunidade lhe está permitido violar o direito de reunião, de livre expressão, de nenhuma pessoa, seja membro da comunidade, visitante ou um mero tran- 
seunte” (Etzioni, 2001a, p. 50). A Constituição estabelece limites para os valores particulares das comunidades e o Estado deve proteger todos os membros de todas as comunidades, acima de valores particulares.

Etzioni também não faz concessão ao relativismo transcultural. A posição, em princípio simpática, de que "não há valores mundiais", de que os valores ocidentais - incluída a teoria dos direitos humanos - têm validade apenas no Ocidente por serem componentes de uma cultura específica, é relativista e impede avanços rumo à finalidade maior da perspectiva comunitarista, que é a constituição de uma comunidade mundial de comunidades. Etzioni propõe que se avance nesse caminho mediante diálogos morais de alcance mundial. Avalia que em grande parte as restrições ao direito internacional e a muitas declarações, incluída a Carta das Nações Unidas, tem a ver com a forma como foram elaborados tais documentos. Se fossem frutos de um parlamento 118 mundial ou de um tribunal mundial representativo obteriam reconhecimento muito maior. A proposta comunitarista é pela construção democrática de um núcleo limitado de valores globalmente compartilhados. "Os diálogos morais transculturais se constituem sobre a base de valores globais substantivos, valores que formulam uma exigência a todos e não guardam relação específica com uma comunidade ou sociedade em particular" (Etzioni, 1996, p. 278). No mesmo sentido está o chamamento moral à provisão de bases socioeconômicas aos membros de todas as comunidades, indispensável para assegurar liberdades políticas e democracia em escala global.

\section{Lei e moral}

Para que uma sociedade seja comunitária "grande parte da conduta social deve ser 'regulada' mais pela confiança na voz moral do que na lei, e o alcance da lei deve limitar-se em grande medida ao que a voz moral sustenta" (Etzioni, 1996, p. 
169). Em outras palavras, “a lei, na sociedade comunitária, é primeiro e acima de tudo a continuação da moralidade por outros meios" (Etzioni, 2004, p. 158). Leis têm pouca capacidade de transformar relações sociais. As leis "que pegam” são as que se embasam nos valores aceitos pelas pessoas, havendo um processo de retroalimentação entre leis e valores. Os valores morais estão em constante transformação, acompanhando a vida em sociedade e as mudanças no interior das comunidades. A elaboração legislativa deve levar em conta a cultura e as mudanças morais. Vale mais a cautela do que a pressa em propor novas leis.

O que há nas sociedades ocidentais das últimas décadas é o excesso de leis, paralelamente ao decréscimo da força moral das comunidades. A expectativa exagerada na capacidade das leis moldarem condutas e transformar hábitos é enganosa, ilustrada por fatos como o fracasso da proibição do consumo de álcool, do aborto ou do divórcio, que tenderam inclusive a ter o efeito contrário. A eficácia das leis depende de sustentação moral. "As normas legais se desenvolvem melhor secundando os novos princípios morais compartilhados do que tratando de exercer a liderança para a sua transformação" (Etzioni, 2001a, p. 48). São exemplos bem-sucedidos a afirmação dos direitos civis, a redução do tabagismo e as condutas pró-meio ambiente nos Estados Unidos, decorrentes muito mais dos novos valores assumidos pelas pessoas do que de proibições e coações legais.

O fundamento do direito comunitário está na seguinte proposição: "em uma boa sociedade, o direito é primeiro e antes de tudo a continuação da moral por outros meios" (Etzioni, 2001b, p. 173). Não se exclui a possibilidade de o direito conduzir até certo ponto uma mudança social, mas se a cultura moral não acompanha de perto o direito haverá uma crescente tendência da ordem social em direção ao autoritarismo. 


\section{Diálogos morais e megálogos}

A cultura moral de uma comunidade se forma e se transforma mediante diálogos morais, que ocorrem permanentemente em conversações cotidianas (nas casas, nos bares, nas escolas, nos locais de trabalho e de lazer) e por vezes em reuniões, assembleias e eventos formais. Os diálogos morais ${ }^{12}$ consistem, no essencial, na avaliação e discussão acerca de convicções e crenças que regem o comportamento das pessoas, como as questões acerca das nossas obrigações em relação ao meio ambiente, aos direitos da mulher, à união de homossexuais, à penalização de jovens e crianças e à crueldade contra animais, entre outras (Etzioni, 2001a, pp. 61 e ss.). Não são discussões entre especialistas e, sim, entre cidadãos, mais de natureza ética que lógico-empírica.

Se isso se aplica a uma comunidade local, pequena, será viável também em sociedades inteiras? Etzioni acredita que sim. O processo constante das conversações morais não 120 se esgota no plano local. Milhares de conversações locais acabam por constituir redes que abarcam toda a sociedade, redes tecidas em encontros regionais e nacionais da sociedade civil, dos partidos, de órgãos estatais e dos vínculos eletrônicos via internet. Esses grandes diálogos são os megálogos. Frequentemente, os megálogos são "amplos, desordenados (não seguem um padrão claro), seu começo é confuso e não chegam a conclusões claras ou decisivas. Todavia, em sociedades relativamente comunitárias os megálogos conduzem a mudanças significativas nos valores nucleares" (Etzioni, 2001b, p. 136).

A cada vez, alguns poucos temas se sobressaem nos diálogos morais entre as pessoas e nos meios de comunicação de uma sociedade nacional, temas esses que constituem os megá-

\footnotetext{
12 O conceito de diálogo moral é central em Etzioni, a ponto de o autor considerá-lo o principal conceito que diferencia o pensamento comunitário do liberal (Etzioni, 2001 b, p. XIX).
} 
logos. Os meios de comunicação são um importante espaço de constituição dos megálogos e exercem sobre aqueles expressiva influência, que, todavia, não deve ser sobrevalorizada a ponto de considerar que seguem necessariamente a voz da mídia.

Os megálogos são o principal meio de transformação da cultura moral: "a melhor maneira de mudar a direção de uma sociedade é produzir um megálogo acerca da substância dos valores de seus membros e da intensidade dos seus compromissos com os valores que afirmam" (Etzioni, 2001b, p. 170). Entre as questões apontadas por Etzioni como temas relevantes para megálogos nas sociedades comunitárias estão as que afetam a reforma do Estado de bem-estar, como o enfrentamento da desigualdade, o equilíbrio entre centralização e descentralização e a construção de uma comunidade de comunidades.

\section{Concepção sociopolítica}

A comunidade está no centro da concepção sociopolítica do comunitarismo responsivo e é indispensável para a boa sociedade. Isso não significa que esteja acima do indivíduo: indivíduos e comunidades são mutuamente constitutivos e suas relações são ao mesmo tempo complementares e tensas. O comunitarismo responsivo recusa o coletivismo. $\mathrm{O}$ pertencimento comunitário significa que a pessoa é parte integral, mas não é nem consumida, nem absorvida pela comunidade (Etzioni, 1996, p. 18).

Tendo vivido a experiência dos kibbutzin israelenses na juventude (alguns dos quais pendiam excessivamente ao coletivismo), vivendo num ambiente social inclinado exageradamente ao individualismo e coerente com a melhor tradição comunitarista (a tradição judaica e cristã, o socialismo utópico, o liberalismo social, os comunitaristas responsivos, o republicanismo cívico), Etzioni desenvolve um pensamento voltado à afirmação do equilíbrio entre o coletivo e o individual, a ordem social e a autonomia, as responsabilidades e os direi- 
$\operatorname{tos}^{13}$. Confrontando o discurso neoconservador, de um lado, e o discurso individualista, de outro ${ }^{14}$, o autor propõe a substituição da antiga regra de ouro, que estabelecia a prevalência do bem comum e da ordem social, por uma nova regra de ouro: "respeita e defende a ordem moral da sociedade da mesma maneira que queres que a sociedade respeite e defenda tua autonomia” (Etzioni, 1999a, p. 18).

Em vista do contexto de sua obra, Etzioni dedica muitas páginas à desmistificação dos dogmas individualistas, expressos, por exemplo, no campo das políticas públicas pela defesa incondicional da autonomia individual e da privacidade. A privacidade é um valor fundamental da democracia; sem privacidade nenhuma sociedade é livre. Mas o que se tornou frequente nos Estados Unidos a partir dos anos 1960 é a defesa unilateral da privacidade, desacompanhada da preocupação com o bem comum, presente na cultura cívica, nas políticas sociais e nas doutrinas legais.

122 Os imoderados campeões da privacidade (incluindo a American Civil Liberties Union - ACLU, de honorável trajetória em favor dos direitos civis) estiveram engajados não só em excessos retóricos, mas fizeram oposição a todas as políticas voltadas ao bem comum que tenham significado de algum modo a limitação da privacidade (exemplos: testes de teor alcoólico, de HIV, revistas íntimas e rastreamento da trajetória pessoal para exercício de certas funções, entre outras). A posição comunitarista pelo equilíbrio significa um grande cuidado com a privacidade, mas, ao mesmo tempo, avali-

\footnotetext{
${ }^{13}$ A respeito do equilíbrio entre direitos e responsabilidades, Etzioni observa que a Declaração Universal dos Direitos Humanos resta incompleta por não ter sido ainda incluída a declaração de responsabilidades (Etzioni, 2004, p. 3).

${ }^{14}$ Etzioni (1999a, pp. 28-29) situa no campo individualista autores como John Locke, John Stuart Mill, Adam Smith, John Rawls, Ronald Dworkin, T. M. Scanlon, Stephen Holmes, Thomas Nagel, Milton Friedman e Friedrich Hayek. No campo social-conservador, Gertrude Himmelfarb, Michael Oakeshott, Samuel Huntington, Diane Ravitch, Russel Kirk, Harvey Mansfield, Linda Chavez, Paul Weyrich, Stanley Hauerwas, Richard Neuhaus, Alasdair MacIntyre, William Benett e George Will, entre outros.
} 
za políticas que em certos casos limitam a privacidade em nome da proteção do bem comum (Etzioni, 1999b; 2004).

As sociedades comunitaristas requerem ordem, uma ordem voluntária, fundada especialmente em meios normativos (educação, liderança, consenso, pressão dos pares, exibição de modelos, exortação, vozes morais da comunidade). Uma ordem moral que requer a restauração cívica, a retomada dos valores cívicos que fazem parte da trajetória da sociedade norte-americana e que nas últimas décadas foram suplantadas pela visão individualista, mas sempre respeitosa dos direitos individuais. Ordem marcada por um pluralismo limitado por valores compartilhados (Etzioni, 1999a).

Dada a exacerbação do discurso dos direitos, Etzioni e os comunitaristas responsivos propugnaram uma moratória de direitos nos Estados Unidos e a retomada das virtudes sociais: "o retorno à linguagem das virtudes sociais, interesses, e, acima de tudo, responsabilidades sociais irá reduzir a litigiosidade e reforçará a cooperação social” (Etzioni, 1993a, p. 7). A reivindicação de direitos sem as responsabilidades correlatas é antiética e ilógica. Direitos presumem responsabilidades. Do mesmo modo, a insistência nas responsabilidades presume a afirmação de direitos (Etzioni, 1996).

\section{O equilíbrio entre Estado, comunidade e mercado}

A boa sociedade é caracterizada pelo tripé Estado-comunidade-mercado em equilíbrio, esferas complementares que devem atuar sinergicamente uma vez que cada qual tem uma contribuição própria e insubstituível, que não pode ser adequadamente suprida por outra. A terceira via etzioniana considera que o Estado tem entre suas principais atribuições a segurança pública, a saúde pública, a regulação do mercado e a proteção ambiental. O mercado é o melhor motor para a produção de bens e serviços, de geração de oportunidades de trabalho, de emprego e de progresso econômico. E a comunidade é a melhor alternativa para a prestação de 
uma série de serviços sociais e indispensável para a difusão de valores morais compartilhados (Etzioni, 1999a; 2001a; 2007).

Nas sociedades ocidentais atuais a comunidade é o sócio preterido do tripé, avalia Etzioni, havendo necessidade de um reforço substancial de seu papel. O desmerecimento do papel das comunidades está associado à manutenção da dicotomia público/privado: para o suprimento das necessidades sociais tende-se a buscar ou a via estatal ou a privada, olvidando que a melhor alternativa em muitos casos é a via comunitária. $\mathrm{O}$ autor preconiza a superação da dicotomia público/privado via o uso de modelos híbridos nas políticas públicas, em que Estado, comunidade e mercado aparecem juntos. Alguns exemplos de modelos híbridos: a) serviços sociais prestados por instituições religiosas e associações de voluntários parcialmente financiadas pelo governo; b) organizações privadas sem fins lucrativos (universidades, teatros, museus) que contam com recursos estatais, mas que se man124 têm no principal com dinheiro auferido com doações, taxas e rendas; c) vales estatais, com os quais os cidadãos podem adquirir serviços da comunidade ou produtos do mercado (auxílio-moradia, pré-escola); d) sistemas públicos de televisão e mídias na forma de sociedade mista, com cotas adquiríveis pelos usuários. E acrescenta: "Há atualmente um leque muito maior de possibilidades para fazer combinações em assuntos relacionados à provisão de serviços essenciais (especialmente água), serviços públicos (como transporte urbano e escolas) e outros. É chegada a hora de superar a dicotomia simplista mercado e Estado" (Etzioni, 2001a, p. 89).

\section{Subsidiariedade e fortalecimento das comunidades}

A sociedade comunitarista promove a subsidiariedade, a solução local de problemas que estejam ao alcance de famílias, vizinhança e pequenas comunidades, devendo as instituições intermediárias e instâncias do Estado desempenhar os serviços de maior escala. 
Etzioni, na senda da tradição tocquevilliana e do socialismo não marxista, faz uma leitura comunitarista da subsidiariedade, enaltecendo o papel das comunidades e das instâncias de poder local ${ }^{15}$. As comunidades podem desempenhar um papel relevante no âmbito das políticas sociais, com maior qualidade humana que o Estado. Sua importância é tamanha que "as comunidades podem chegar a ser a mais importante nova fonte de serviços sociais no futuro previsível" (Etzioni, 2001a, p. 30). Isso não quer dizer que em sociedades complexas as comunidades possam assumir a maioria dos serviços prestados pelo Estado, e, sim, que uma parte deles pode lhes ser "devolvida" ou desenvolvida de forma mista. $\mathrm{O}$ autor alerta que cabe analisar com cuidado a fusão de instituições locais/regionais em nome de maior eficiência, pois os benefícios contábeis podem não compensar os custos daí decorrentes ao tecido social.

Para que possam cumprir seu papel, as comunidades devem ser fortalecidas por políticas públicas como a disponibilidade de instituições e equipamentos públicos locais; a melhoria e a segurança dos espaços públicos; a abertura à participação na tomada de decisões; a adequação da geografia administrativa das instituições públicas à vida das comunidades; a adaptação das políticas a unidades sociais menores; e a cooperação entre comunidades e polícia, entre outras (Etzioni, 2001a).

\section{Boa sociedade e sociedade civil}

Etzioni é um ardoroso defensor do papel da sociedade civil, cívica, na construção da boa sociedade. Dedica uma obra importante - The active society (1968) - à formulação de uma teoria voltada à construção de uma sociedade livre - cujo núcleo é a ideia da sociedade ativa e do cidadão ativo - na pas-

15 Otfried Höffe (2005) lembra que historicamente a subsidiariedade ensejou interpretações que destacam mais o valor do indivíduo que da comunidade, o que não é o caso de Etzioni. 
sagem da sociedade moderna à sociedade pós-moderna. Em cada molécula social, em cada coletividade há energia latente suficiente para a ampla realização de valores. É preciso liberar e canalizar essa energia latente, transformá-la em energia pública. O incremento do conhecimento e da tecnologia, próprio da sociedade pós-moderna, carrega virtualidades da sociedade ativa, mas para que se materialize é necessária a expansão da orientação ativa, constituída por três componentes principais: a autoconsciência, o compromisso com objetivos e o acesso a níveis de poder. "Ser ativo é ser consciente, comprometido e potente" (Etzioni, 1968, p. 5). Enquanto a sociedade passiva é marcada por aquiescência, reatividade, tribalismo e nacionalismo, a sociedade ativa é proativa, aberta e cosmopolita. A construção de autênticas comunidades serve a essa finalidade maior da edificação da sociedade ativa.

Como Buber, Etzioni ressalta a distinção e a supremacia do princípio social sobre o princípio político ${ }^{16}$. "A ação social, 126 como a que tem lugar em e entre os membros da família, os vizinhos, as associações de voluntários e as comunidades, é prioritária em relação à ação política”, assinala o autor, complementando que "aqui difiro daqueles que tendem frequentemente, inadvertidamente, a equiparar ação social com ação política e sociedade com Estado" (Etzioni, 1999a, p. 171). Os liberais acreditam nas virtudes do livre mercado, os social-conservadores, nas virtudes do bom Estado e os comunitaristas, nas virtudes da boa sociedade (Etzioni, 2004). Essa visão nada tem a ver com a desvalorização da ação política; pelo contrário, a revitalização da política é uma tarefa inadiável. Etzioni assume a perspectiva republicana do cidadão ativo e virtuoso, interessado, informado, que vota, participa de assembleias e

${ }^{16}$ O político não é o social. A tendência de subsumir o social no político vem desde a noção aristotélica da natureza política do ser humano, mas a interpretação adequada da teoria aristotélica é que "os seres humanos são sociais por natureza, que cooperam e compartilham significados e fins, e não que a essência do seu ser é estar relacionado ao estado ou por ele mitigado" (Etzioni, 2004, p. 14). 
debates, integra organizações sociais, insere-se em manifestações públicas, acompanha e fiscaliza a ação dos agentes políticos. Em diversas obras expõe críticas mordazes à política norte-americana ao dizer que na maior parte não passa da defesa de interesses particulares e que está eivada de corrupção. É preciso recapturar a política para os fins da comunidade (Etzioni, 1993a, cap. 8).

Do ponto de vista da distribuição de bens, a boa sociedade assegura a todos um mínimo básico satisfatório, ou seja, um conjunto de bens básicos como alimento, habitação segura, vestimenta e assistência à saúde. Etzioni assina o compromisso da esquerda social-democrata: "ninguém pode ver-se completamente privado da assistência do Estado de bem-estar ou abandonado na rua, inclusive quando se negue a trabalhar, assistir aulas ou a desempenhar serviços comunitários" (Etzioni, 2001a, p. 57).

Ao tratar do papel da sociedade civil, Etzioni insiste numa questão conceitual: o termo civil. Quando se fala em sociedade civil ou cívica, a civilidade em geral é entendida como a maneira cordata de tratar problemas e para destacar os estamentos intermediários entre o indivíduo e o Estado. Essa noção de civilidade assegura uma boa comunicação entre os cidadãos, mas pouco se ocupa de questões normativas, do que é correto e incorreto. Essa concepção é insuficiente: não basta uma sociedade civil, é preciso uma boa sociedade, uma sociedade virtuosa, com um núcleo de valores compartilhados. Não se trata apenas de revitalizar a sociedade civil e, sim, de remoralizar a sociedade. Nesse sentido o autor busca diferenciar-se de Habermas, Putnam ${ }^{17}$ e outros autores que enaltecem os

\footnotetext{
${ }^{17}$ Etzioni, de modo geral, desenvolve análises próximas àquelas de Robert Putnam e outros teóricos do capital social, particularmente no que diz respeito à influência de fatores sociais na economia. Ele avalia que seu conceito de capital social (laços sociais e normas de reciprocidade) é, em boa parte, convergente com o conceito de comunidade, mas sua principal restrição a Putnam é a despreocupa-
} 
vínculos sociais sem preocupar-se suficientemente com os valores compartilhados pelas organizações sociais (Etzioni, 1999a, pp. 123 e ss.).

Essa abordagem se reflete na concepção de democracia. Para Etzioni, grande parte dos autores identificados com a democracia deliberativa concebe a deliberação nos termos da civilidade, como ato racional, desvinculado de emoções e sentimentos, uma concepção racionalista tipicamente liberal. O deliberacionismo racional (a concepção racionalista da democracia deliberativa) é uma romantização da deliberação e choca-se com o fato de que no ato deliberativo os seres humanos não são agentes isolados ou supridos de software analítico, mas membros de uma comunidade que carrega seus valores morais quando se reúnem para tomar decisões. A dimensão normativa envolve todas as decisões: "quando se adota uma posição relacionada com problemas capitais de política, a eleição de valores domina tudo" (Etzioni, 1999a, 128 p. 123). Assim, a democracia deliberativa deve incorporar a lógica dos diálogos morais, do diálogo sobre valores (Etzioni, 1996; 2004). Três procedimentos são próprios dessa metodologia: (i) chamamento a um valor dominante compartilhado pelas várias partes; (ii) trazer um terceiro valor quando há dois em conflito; e (iii) a educação, a persuasão e a liderança de valores. Esses procedimentos têm um elemento comum: o de que uma pessoa é capaz de mudar os valores ou as preferências de outros, aspecto alheio ao pensamento individualista. Trata-se de diálogos de convicções, não de meros diálogos procedimentalistas (Etzioni, 1999a, pp. 131 e ss.).

ção com os valores morais das associações e das organizações: "sem valores compartilhados, as comunidades não são capazes de resistir a forças centrífugas"; as entidades comumente vistas como comunidades tendem a ter um núcleo de valores compartilhados e por isso "os principais pilares da comunidade não podem ser ligas de boliche, sociedades de observação de aves e clubes de xadrez. Embora elas possam fornecer alguma medida de laços sociais, ainda que bastante tênues, são triviais como fontes de novas formações de valores morais comuns [...]" (Etzioni, 2001c). 


\section{Pluralismo cultural e unidade}

As abundantes lutas por razões étnicas e culturas das últimas décadas mundo afora nos alertam, segundo Etzioni, para o fato de que a existência de comunidades fortes pode estar associada à intolerância intercomunitária. As versões extremadas de autocentração comunitária são um fator de violência intergrupal. O paradigma sociopolítico está desafiado a mostrar as vias pelas quais se pode fortalecer tanto os laços da comunidade ampla quanto os das comunidades particulares. A imagem mais adequada para ilustrar o pluralismo com unidade em âmbito nacional (o modelo da comunidade de comunidades) é o mosaico: "o mosaico simboliza uma sociedade na qual diversas comunidades mantêm suas particularidades culturais [...] Ao mesmo tempo, estas distintas comunidades reconhecem que são partes integrais de um todo mais amplo" (Etzioni, 1999a, p. 228). Contra os extremos do assimilacionismo (tentativa de converter todos os grupos a uma comunidade geral) e das políticas de identidade (defesa do direito às diferenças culturais, sem unidade) trata-se de estabelecer que o respeito à diversidade cultural é limitado por valores gerais da sociedade, assentados na Constituição. Os valores gerais estão acima dos valores particulares das comunidades, mas deve haver da parte das autoridades sensibilidade para não tensionar desnecessariamente os valores particulares das subculturas. Um exemplo de integração com respeito às particularidades refere-se à língua: a aprendizagem da língua oficial do país pelos imigrantes além de um dever é um direito, que não impede o cultivo da língua original. Em vez de políticas de identidade, políticas de reconhecimento, assentadas em diálogos morais que buscam o equilíbrio entre o particular e o geral (Etzioni, 2001a).

É inegável que a concepção etzioniana está isenta de acusações que consideram o comunitarismo um discurso em favor de particularismos culturais e de incentivo aos confli- 
tos interculturais, ou, por outro lado, de defesa de uma globalização homogeneizadora, que sufoca as diferenças entre os povos. O modelo da comunidade de comunidades é uma proposta de integração e de respeito às diferenças, tanto no âmbito do país como no do planeta.

\section{Concepção econômica}

Etzioni realiza um empreendimento de grande envergadura intelectual ao propor um paradigma inovador, o paradigma sociopolítico ou paradigma Eu-Nós, alternativo ao paradigma neoclássico, predominante no contexto norte-americano e ocidental do fim do século XX. O novo paradigma, sistematizado no livro The moral dimension: towards a new economics (1988), teve grande repercussão nos meios científicos e tornou-se uma referência central para a socioeconomia e a estruturação da SASE. A socioeconomia é a teoria econômica desse novo paradigma e procura explicar o comportamento 130 econômico à luz de variáveis sociais, psicológicas e políticas.

Esquematicamente, o paradigma neoclássico tem como premissas centrais: (i) os indivíduos são movidos pelo autointeresse, tomando decisões com base na expectativa de maximizar seus benefícios; (ii) as escolhas dos indivíduos derivam de um cálculo racional, cujo núcleo é o autointeresse; (iii) as escolhas dos indivíduos são fundamentalmente escolhas pessoais; o indivíduo é a unidade de tomada de decisão.

O paradigma sociopolítico sustenta-se sobre bases radicalmente distintas: (i) grande parte das decisões das pessoas não se apóiam no autointeresse; as pessoas decidem com base em ao menos duas fontes de valoração: o prazer e a moralidade; (ii) a unidade de tomada de decisões são as coletividades sociais; (iii) os valores e as emoções têm destacado papel nas decisões; a capacidade racional dos indivíduos é limitada e envolta na dimensão afetivo-valorativa; (iv) o mercado não constitui uma esfera separada; é um subsistema da sociedade (Etzioni, 1993b; 2007). 


\section{0 mercado é um subsistema da sociedade}

O mercado não é uma esfera separada da sociedade, mas está imerso numa cápsula social, que é a sociedade. O alcance e a variedade das transações que acontecem no mercado e as formas de competição entre os agentes e os grupos econômicos são em grande medida determinados pela sociedade. Etzioni opõe-se terminantemente à concepção neoliberal do mercado como uma esfera independente e autorregulada, rejeita a visão da concorrência perfeita, bem como a prevalência dos valores mercantis da sociedade na vida social. O mercado é uma das pernas do tripé da boa sociedade e jamais pode ser o centro gerador dos valores que organizam o convívio social.

O mercado não é algo negativo, ao contrário: é o melhor motor para a produção de bens e serviços e para o progresso econômico, mas só o mercado regulado é compatível com a boa sociedade. A competição no mercado é uma forma de conflito, que deriva de interesses e objetivos divergentes dos indivíduos, os quais postos juntos jamais formam um conjunto harmonioso. São indispensáveis mecanismos para conter e proteger a competição, prevenindo uma escalada que pode conduzir à autodestruição. Indo além da oposição conceitual entre competição livre e intervenção da administração, a socioeconomia adota o conceito de competição encapsulada, que prevê que "o contexto social que limita a finalidade da competição não é simplesmente uma fonte de restrições para o mercado, mas também uma precondição para a sua capacidade de funcionar" (Etzioni, 2007, p. 263). Trata-se de buscar um nível apropriado de competição. A competição adequadamente limitada é uma força construtiva; a competição desatada é fortemente destrutiva; a competição reprimida perde seu poder criativo.

Os principais mecanismos para o controle da competição em níveis aceitáveis são os fatores normativos, sociais e administrativos. Etzioni destaca a importância dos fatores 
normativos. Todas as sociedades têm sistemas de valores que orientam as condutas legitimadas socialmente e esses valores influenciam fortemente a competição. Um primeiro aspecto dessa contenção diz respeito à crença nas virtudes morais da competição em geral. Nos Estados Unidos, por exemplo, é muito forte a crença nas virtudes do livre mercado, enquanto em outras sociedades prevalece uma visão menos otimista e mais favorável à limitação da concorrência. Outro aspecto é o da visão sobre as regras do jogo, se vale a pena ganhar a qualquer custo ou se só vale a pena ganhar com regras justas. Um terceiro aspecto é a constatação de que certas normas ajudam a manter baixos os custos de transação. Um exemplo é o da confiança entre os agentes econômicos: grande parte das transações é feita por meios que envolvem confiança interpessoal. Na mesma linha que Coleman, Putnam e outros intelectuais afinados com o conceito de capital social, Etzioni ressalta a importância da confiança no ambiente econômico, confiança 132 entendida como "uma variável contínua e não dicotômica; é mais elevada em algumas indústrias, subculturas e variedades que em outras. Quanto mais débeis são os fatores normativos relevantes e, portanto, quanto mais débil é a confiança, maiores são os custos de transação" (Etzioni, 2007, p. 269).

Os vínculos (laços) sociais existentes tanto no nível micro como no macrossocial desempenham igualmente um papel importante na limitação da competição. Os vínculos sociais tendem a unir as pessoas por sentimentos mútuos positivos, muitas vezes potencializados por compatibilidades étnicas, de classe, de personalidade, de geração ou outras. Etzioni propõe a hipótese de uma relação curvilínea entre vínculos sociais e competição: mantidos os demais aspectos envolvidos, quando os laços sociais são débeis ou inexistentes, a competição tende ao conflito total (caso de greves amplas e destrutivas, sabotagem e violência); quando há laços sociais fortes, a competição tende a se estabilizar em limites que não desestruturam a cápsula social. Daí o entendimento de que "a competi- 
ção não prospera em sistemas impessoais [...] mas no nível médio, onde os vínculos sociais são suficientemente fortes para manter a confiança mútua e os custos de transação baixos, porém não tão fortes que suprimam a orientação ao intercâmbio" (Etzioni, 2007, p. 273). Mais que entre estranhos totais, menos que entre parentes e amigos, a competição controlada pressupõe a distinção entre comportamentos ofensivos (por exemplo, tramoias) e comportamentos aceitáveis ou toleráveis. Nesse ponto, os laços sociais e os fatores normativos se entrecruzam.

A administração também desempenha um papel próprio no modelo da competição encapsulada. Em decorrência dos conflitos endêmicos do mercado, é indispensável o papel de árbitro e de dissuasão da violência exercido pelas instâncias estatais. As leis que protegem a propriedade privada, a moeda, a proibição da fraude e da violência ajudam a manter a cápsula social que envolve a competição do mercado. Mas, quando o governo leva longe demais seu papel e influencia no resultado da competição, ele sufoca a concorrência e coloca em risco a cápsula social. Quanto mais fortes são as proibições morais e os laços sociais, menos necessária é a ação governamental. Quanto maior a preocupação em limitar os freios da coação administrativa, maior deve ser o reconhecimento do valor dos mecanismos normativos da comunidade (Etzioni, 2007, p. 275).

As décadas de 1960 e 1970 assistiram ao auge e à queda do marco analítico de John Rawls, a década de 1980 viu o triunfo do individualismo e do mercado de Hayek e a década de 1990 acompanhou a ascensão do comunitarismo (Parsons, 2003).

Etzioni é um dos expoentes do pensamento comunitarista atual e a recepção crítica de seu pensamento no cenário 
brasileiro é promissora para os estudos voltados à inovação sociopolítica. Há quem o considere (Adán, 2006) o mais importante sociólogo do nosso tempo, pela envergadura de sua obra e por sua condição de intelectual público. San Roman (2007, p. 9) enaltece três aspectos no autor: "tem pensamento próprio, apoia suas afirmações em numerosas e atualizadas investigações sociais empíricas e dedica bastante tempo a difundir seu pensamento tanto em foros científicos como nos meios de comunicação”. Pablo Guerra (2006) assinala que seu pensamento traz contribuições importantes para uma plataforma comunitarista latino-americana, como a crítica ao individualismo, o chamado à revitalização das instituições familiares, o papel da escola na formação do caráter, a participação política dos cidadãos e o enfrentamento da corrupção, observando que há assuntos pendentes que requerem uma abordagem própria vista do nosso continente.

Este artigo procurou mostrar que a densa formulação 134 comunitarista de Etzioni não foi antecipada em suas obras iniciais, dedicadas à sociologia organizacional e influenciadas pelo funcionalismo, embora o autor reivindique continuidade e coerência no conjunto de sua produção, afirmando que há um subtexto moral pouco notado em sua teoria organizacional. Certo é que os textos da maturidade têm outro objeto e outra envergadura. Ocupam-se de temas abrangentes do pensamento filosófico-sociológico, nas dimensões política, social, antropológica, moral e econômica. A preocupação básica do autor é fundamentar a tese de que as comunidades são essenciais para a boa sociedade e que é imperioso fortalecê-las num contexto em que estão depreciadas diante do Estado e do mercado.

A terceira via comunitarista traz inflexões distintas das versões social-democratas conhecidas no Brasil. Duas teses são particularmente interessantes para o debate político brasileiro. Uma é a ênfase no equilíbrio entre comunidade e indivíduo, entre bem comum e autonomia individual, postulado que 
afasta o comunitarismo da suspeita de ser uma nova forma de coletivismo e que lança uma ponte entre o socialismo e o liberalismo, exigência que Bauman (2003) e Mouffe (2006) reputam como fundamental para o futuro das teorias comunitárias. A outra é a concepção de que a boa sociedade requer o equilíbrio do tripé Estado-comunidade-mercado. Tal equilíbrio supõe que cada uma das partes do tripé é insubstituível em suas funções e que o comunitarismo não pretende substituir os excessos do Estado (estatismo) ou do mercado (privatismo) pela supervalorização da comunidade. O que o comunitarismo reivindica é o fortalecimento da comunidade, num contexto em que está depreciada pelo individualismo, e a sinergia do comunitário com o estatal e o privado. Esse entendimento favorece a inovação sociopolítica, ao permitir a superação de visões simplistas e dicotômicas, como a de que a carência de serviços públicos requer sempre a criação de novas estruturas estatais ou que a única alternativa aos serviços estatais ineficientes é a privatização. A inclusão da alternativa comunitária é inovadora e, segundo mostra a experiência internacional, em muitos casos as entidades comunitárias executam serviços públicos com melhor relação custo/benefício e, em outros, o mais adequado pode ser a opção por um modelo cooperativo entre entes estatais, comunitários e privados (Parsons, 2003).

A transposição de teorias de um país a outro é inviável, embora a globalização crie cada vez mais elementos comuns entre os continentes. No plano da análise política e social resta comprovar a fertilidade do pensamento etzioniano para o Brasil. Como lembram os sociólogos Robert Bellah (1999) e Hans Joas (2001), o discurso sobre comunidade nos Estados Unidos, no qual se inscreve Etzioni, deve ser lido à luz das peculiaridades daquele contexto. Joas (2001, p. 95) diz que “o discurso sobre 'comunidade' nos Estados Unidos tem sempre sido parte da comunicação dentro da sociedade liberal-democrática", enquanto na Alemanha “o 
debate é travado em uma sociedade fundamentalmente não liberal". Essa observação vale também para o Brasil. Nossa lógica política não é a de uma típica sociedade liberal-democrática, somos herdeiros não da tradição anglo-saxã e, sim, da cultura ibérica; nossa polarização não se dá entre republicanos e democratas, nem temos a experiência histórica das comunas, festejadas por Tocqueville. Aqui, o Estado precedeu a sociedade civil, o patrimonialismo e o clientelismo vêm de longa data, a participação dos cidadãos nos assuntos públicos mantém-se limitada e o grau de desigualdade econômica e social ainda é dos maiores do mundo.

\section{João Pedro Schmidt}

é professor do Departamento de Ciências Humanas e do Programa de Pós-Graduação em Direito da Universidade de Santa Cruz do Sul (UNISC).

\section{Bibliografia}

ADÁN, J. P. 2006. "Presentación”. In: ETZIONI, A. El guardian de mi hermano: autobiografia y mensaje. Madrid: Astor Juvenil Palabra, pp. 5-17.

BAUMAN, Z. 2003. Comunidade. Rio de Janeiro: Jorge Zahar.

BELLAH, R. N. 1999. "Comunitarismo ou liberalismo? Brasil e Estados Unidos em debate. In: SOUZA, Jessé. O malandro e o protestante: a tese weberiana e a singularidade cultural brasileira. Brasília: Edunb, pp. 295-315.

BELL, D. 1993. Communitarianism and its critics. Oxford: Clarendon Press. 2009. Communitarianism. In: Standford Encyclopedia of

Philosophy. Disponível em: <http://plato.stanford.edu/entries/

communitarianism>. Acesso em: 27 dez. 2014.

BUBER, M. 2001. Eu e tu. São Paulo: Centauro.

. 2006. Caminos de utopia. México: FCE.

2008. Sobre comunidade. São Paulo: Perspectiva.

CITTADINO, G. 2009. Pluralismo, direito e justiça distributiva: elementos da filosofia constitucional contemporânea. $4^{\mathrm{a}}$ ed. São Paulo: Lumen Juris. COSTA, S.; WERLE, D. 1997. "Reconhecer as diferenças: liberais, comunitaristas e as relações raciais no Brasil". Novos Estudos CEBRAP, n. 49, nov., pp. 159-78.

DIAS, R. 2008. Sociologia das organizações. São Paulo: Atlas.

ETZIONI, A. 1967. Organizações complexas: um estudo das organizações em face dos problemas sociais. São Paulo: Atlas. 1968. The active society: a theory of societal and political processes.

London/New York: Collier-Macmillan/The Free Press. 
1974. Análise comparativa de organizações complexas: sobre o poder, o engajamento e seus correlatos. Rio de Janeiro/São Paulo: Zahar/Edusp. 1976. Organizações modernas. 5. ed. São Paulo: Pioneira. 1993a. The spirit of community: the reinvention of American society.

New York: Touchstone. . 1993b. Public policy in a new key. New Brunswick and New Jersey:

Transaction Publishers. . 1995. "The attack on community: the grooved debate". Society, v. 32, n. 5, jul./ago., pp. 12-17. Disponível em: <http://www.gwu.edu/ ccps/ etzioni/A239.html>. Acesso em 4 jan. 2012. 1996. (ed.). New communitarian thinking: persons, virtues, institutions, and communities. 3. ed. Charlottsville and London: University Press of Virginia. . 1998. "Introduction". In: ETZIONI, A. (ed.). The essential communitarian reader. Lanham, Rowman \& Littlefield Publishers, p. IX-XXIV. 1999a. La nueva regla de oro: comunidad y moralidad en una sociedad democrática. Barcelona: Paidos Iberica. 1999b. The limits of privacy. New York: Basic Books. . 2001a. La tercera via: hacia una buena sociedad. Propuestas desde el comunitarismo. Madrid: Trotta.

. 2001b. The monochrome society. Princeton and Oxford: Princeton

University Press. 2001c. "Is bowling together sociologically lite?". Contemporary

Sociology, v. 30, n. 3, maio. Disponível em: <http:/ /www.gwu.edu/ ccps/ etzioni/A286.html>. Acesso em: 4 jan. 2012.

. 2003. "Communitarianism". In: CHRISTENSEN, K.; LEVINSON,

D. (eds.). Encyclopedia of community: from the village to the virtual world. Sage Publications, v.1, pp. 224-28.

. 2004. The Common Good. Cambridge: Polity Press.

2006. El guardian de mi Hermano: autobiografia y mensaje. Madrid:

Astor Juvenil Palabra.

2007. La dimensión moral: hacia una nueva economia. Madrid: Astor Juvenil Palabra.

2009a. "Mixed scanning: uma 'terceira' abordagem da tomada de decisão”. In: HEIDEMANN, F.G.; SALM, J.F. (org.) Políticas públicas e desenvolvimento: bases epistemológicas e modelos de análise. Brasília: Edunb, pp. 219-32.

2009b. "Reexame da estratégia mista de decisão". In: HEIDEMANN, F.G.; SALM, J.F. (org.) Políticas públicas e desenvolvimento: bases epistemológicas e modelos de análise. Brasília: Edunb, pp. 232-49.

GALUPPO, M. C. "A constituição pode fundar uma república?” Revista Brasileira de Direito Constitucional-RBDC, n. 10, jul./dez. 2007, pp. 39-49.

GOHN, M. G. 2004. "Empoderamento e participação da comunidade em políticas sociais”. Saúde e Sociedade, v.13, n.2, pp. 20-31, maio-ago.

GUERRA, P. 2006. “Comunitarismo en América Latina”. In: ADÁN, J. P. Comunitarismo: cultura de solidaridad. Madrid: Sekotia, pp. 93-111. 
HEIDEMANN, F. G.; SALM, J. F. 2009. (orgs.). Políticas públicas e desenvolvimento: bases epistemológicas e modelos de análise. Brasília: Ed. Unb.

HÖFFE, O. 2005. A democracia no mundo de hoje. São Paulo: Martins Fontes.

JOAS, H. 2001. "O comunitarismo: uma perspectiva alemã". In: SOUZA,

J. (org.). Democracia hoje: novos desafios para a teoria democrática contemporânea. Brasília: Ed. Unb, pp. 93-110.

KYMLICKA, W. 2006. Filosofia política contemporânea: uma introdução. São Paulo: Martins Fontes.

LOIS, C. 2005. (org.) Justiça e democracia: entre o universalismo e o comunitarismo: a contribuição de Rawls, Dworkin, Ackerman, Raz, Walzer e Habermas para a moderna teoria da justiça. São Paulo: Landy.

LUCAS, Doglas C. 2009. "Multiculturalismo e o debate entre liberais e comunitaristas: em defesa da interculturalidade dos direitos humanos". Sequência, n. 58, jul., pp. 101-30.

MACEDO, M. de A. 2005. "O comunitarismo na nova configuração das políticas sociais no Brasil . Em Debate 01, PUC-Rio. Disponível em: <http:/ / www.maxwell.lambda.ele.puc-rio.br>. Acesso em: 22 dez. 2011.

MOUFFE, C. 2006. O regresso do político. Lisboa: Gradiva.

NISBET, R. 1982. Os filósofos sociais. Brasília: Ed. Unb.

PAIVA, R. 2003. O espírito comum: comunidade, mídia e globalismo. Rio de Janeiro: Mauad X.

2007. (org.). O retorno da comunidade: os novos caminhos do social.

138 Rio de Janeiro: Mauad X.

PARSONS, W. 2003. Public policy: an introduction to the theory and practice of policy analysis. Cheltenham and Northampton: Edward Elgar Publishing.

RENNÓ Jr., L. 2000. "Indivíduo, comunidade e cultura: fronteiras do debate entre liberalismo e comunitarismo no Brasil”. In: ARAÚJO, E. P. et al. Política e valores. Brasília: Ed. UnB, pp. 223-47.

SAN ROMAN, J. R. 2007. "A modo de presentación: desde el estudio de las organizaciones hasta la socioeconomia y el comunitarismo". In: ETZIONI, A. La dimensión moral: hacia una nueva economia. Madrid: Astor Juvenil Palabra, pp. 9-20.

SCHMIDT, J. P. 2009. (org.) Instituições comunitárias: instituições públicas não estatais. Santa Cruz do Sul: Edunisc.

. 2010. "O comunitário em tempos de público não estatal". Avaliação, Campinas/ Sorocaba (SP), v. 15, n. 1, pp. 9-40, mar.

2011. "Comunidade e comunitarismo: considerações sobre a inovação da ordem sociopolítica”. Ciências Sociais Unisinos, São Leopoldo, v. 47, n. 3, pp. 300-13, set./dez.

SILVEIRA, D. 2007, "Teoria da justiça de John Rawls: entre o liberalismo e o comunitarismo”. Trans/Form/Ação, São Paulo, v. 30, n. 1, pp. 169-90.

TÖNNIES, F. 2009. Comunidad y asociación. Granada: Comares.

TRUCCO, O. 2008. A democracia em Habermas: além do liberalismo e do comunitarismo. Tese de doutorado. Porto Alegre: Universidade Federal do Rio Grande do Sul. 
AMITAI ETZIONI E O PARADIGIMA COMUNITARISTA: DA SOCIOLOGIA DAS ORGANIZAÇÕES AO COMUNITARISMO RESPONSIVO

\section{JOÃO PEDRO SCHMIDT}

Resumo: Amitai Etzioni, principal expoente do comunitarismo responsivo norte-americano, desenvolve uma teoria sistemática em torno do princípio de que as comunidades são indispensáveis à boa sociedade, a qual se caracteriza pelo equilíbrio Estado-comunidade-mercado, donde deriva uma orientação inovadora às políticas públicas, marcada pela sinergia entre as três esferas. O texto apresenta as linhas gerais do percurso intelectual do autor, dos escritos iniciais sobre a sociologia das organizações às obras em que expõe o paradigma sociopolítico, cujos principais conceitos e temas são detalhados.

Palavras-chave: Amitai Etzioni; Comunidade; Comunitarismo; Comunitarismo Responsivo.

\section{AMITAI ETZIONI AND THE COMIMUNITARIAN PARADIGM: FROM THE SOCIOLOGY OF ORGANIZATIONS TO THE RESPONSIVE COMMUNITARIANISIM}

Abstract: Amitai Etzioni, leading exponent of responsive communitarianism, develops a systematic theory around the principle that communities are essential to good society, which is characterized by the state-community-market balance, whence derives an orientation innovative public policies, marked by synergy between the three spheres. The paper presents the outline of the author's intellectual journey, from early writings about the sociology of organizations to the works in that exposes the sociopolitical paradigm, whose main concepts and themes are detailed.

Keywords: Amitai Etzioni; Community; Communitarianism; Responsive Communitarianism. 